\title{
The same pathway to the Weddell Sea birdlife, after 65 years: Similarities in the species composition, richness and abundances
}

\author{
José Luis Orgeira $^{1 *}$, Facundo Alvarez ${ }^{2}$, Constanza Sofía Salvó $^{3}$ \\ ${ }^{I}$ Departamento Biología de los Predadores Tope, Instituto Antártico Argentino, Buenos \\ Aires, Argentina \\ ${ }^{2}$ Programa de pós-graduação em Ecologia e Conservação. Campus de Nova Xavantina, \\ Universidade do Estado de Mato Grosso, Brasil \\ ${ }^{3}$ Departamento Meteorología, Servicio de Hidrografia Naval, Argentina
}

\begin{abstract}
As part of a multi-year study of top predators in Antarctica, we conducted a seabird shipbased survey on board Almirante Irizar icebreaker in the Weddell Sea to the Filchner Ice Shelf in the austral summer 2020. We carried out 10-minute counts along $1843 \mathrm{~km}$ during 125 hours of observation. We analyzed the species distributions and the relationships with the ice cover. We registered 15 species of which four represented more than $85 \%$ of the total abundance: Antarctic petrel Thalassoica antarctica $(43.9 \%)$, snow petrel Pagodroma nivea (16.3\%), Arctic tern Sterna paradisaea (15.2\%) and emperor penguin Aptenodytes forsteri (10.1\%). Species distribution and its relationship with ice cover were analyzed statistically. The ice cover concentration was estimated by using satellite images. We compared our results with the first ship-based bird survey conducted up to the Filchner Ice Shelf in the austral summer 1955/56 to analyze possible changes in the bird community over time. Out of 13 recorded species in the 1955/56 cruise, 11 were present in this study with similar abundance proportions. In both cruises, the bird community consisted of a group of non-numerous species associated with icefree waters and another group of very numerous species associated with high concentrations on ice cover. The similarities between the two cruises, spaced 65 years apart, suggest a temporal persistence of the bird community of the central and the southern Weddell Sea that could be explained by the dynamics of the ice cover and the presence of reproductive colonies within the study site. The current environmental warming is alarming in this bird community because more than $85 \%$ of all its individuals belong to four species strongly dependent on ice cover.
\end{abstract}

Key words: birdlife, Antarctica, ice cover, Antarctic petrel, Filchner ice shelf, warming

DOI: $10.5817 / \mathrm{CPR} 2021-2-20$

\footnotetext{
Received September 20, 2021, accepted November 24, 2021.

*Corresponding author: J. L. Orgeira <jlorgeira@dna.gov.ar>

Acknowledgements: The authors are grateful to the crew of the Icebreaker Almirante Irizar (Armada Argentina) for their assistance provided during the Surveys and to the seabird observers Yohana Jimenez and Juan Cruz Gonzalez. We also want to thank Sara Miranda Almeida for contributions to the development of the NMDS, Diego Montalti and the anonymous reviewers for their collaboration in improving the manuscript. The second author thanks the "Coordenacão de Aperfeiçoamento de Pessoal de Nível Superior-Brazil" (CAPES) - Finance Code 001 for allowing work to be carried out onboard Almirante Irizar icebreaker. This work was carried out with logistic and financial support from Instituto Antártico Argentino.
} 


\section{Introduction}

The Weddell Sea is an extensive oceanic region totally covered with ice in austral winter and partially in austral summer. The ice cover drifts along with the winds and currents to the north, alternating between ice-covered areas and free ones (Ainley et al. 2003). In summer, both sea ice and icebergs offer a refuge to communities of zooplanktonic organisms that support all of the remaining trophic levels (Ferreyra and Schloss 1993, Moore and Abbott 2002, Kahru et al. 2007, Rogers et al. 2020). To conduct studies south of the Weddel sea is associated with logistical difficulties because of climatic variability and the sea ice dynamics. These factors are the reasons for many gaps in the knowledge about fauna of top predators (Teschke et al. 2021). In 1955, when Argentina established its first scientific station on the Filchner Ice Shelf (Belgrano Station, $77^{\circ}$ $47^{\prime} \mathrm{S}, 38^{\circ} 15^{\prime} \mathrm{W}$ ), Novatti (1962) carried out observations of pelagic birds in the Weddell Sea aboard the San Martin icebreaker. Although there were already some previous reports of the area's avifauna, this was the first study done in the Filchner Ice Shelf. Some subsequent studies on the megafauna of the Weddell Sea have been limited to its northernmost area (Zink 1978,

\section{Material and Methods}

\section{Study area}

The Weddell Sea represents the southerly part of the Atlantic Sector of the Southern Ocean. It is bordered to the west by the Antarctic Peninsula, to the north by Clarence Island (South Shetland Island),

\section{Seabird observations}

Seabird surveys were conducted during two cruises, one North-South (NS) towards Belgrano II Station (on Nunatak Bertrab,
Thurston 1982, Joiris 1991, Plotz et al. 1991, van Franeker 1992, 1996, among others), while the other studies focused on the ice shelves in their southernmost points (Novatti 1960, Cline et al. 1969, Schneppenheim 1981, Orgeira and Recabarren 1993, Orgeira 1998, 2000).

Like the rest of Antarctica, the Weddell Sea is under the influence of ongoing environmental changes which cause the collapse of glaciers and ice shelves, impacting on pelagic ecosystems (Smith et al. 2007, Daae et al. 2020). Moreover, the Weddell's ice field has a considerable annual and interannual variability. Although the largest summer ice decrease has been between 2015 and 2017, there are persistent negative anomalies in the sea ice extension and concentration (Turner et al. 2020). In this changing scenario, we conducted a ship-based seabird survey to the Filchner Ice Shelf in summer 2020. Taking into account that the Novatti cruise (1960) was carried out 65 years ago, our objective is to compare both cruises, summer seasons 1955/56 and 2020, in terms of species composition, number of species and abundances to evaluate possible changes in time in the central and the southern Weddell Sea bird community. the South Orkney Islands and the South Thule Islands, to the east by the Land of Coats and to the south by the Filchner and Brunt Ice Shelf.
Filchner Ice Shelf, $77^{\circ} 52^{\prime} \mathrm{S}$ and $34^{\circ} 37^{\prime} \mathrm{W}$ ), from 23 to 26 January, 2020) and the other back from the Filchner Ice Shelf from 
29 January to 2 February, South-North (SN) transect (Fig. 1). Bird data were obtained from opportunistic observations onboard icebreaker Almirante Irizar (Argentine Navy-Dirección Nacional del Antártico) by three observers. Only the counts made when the ships were moving at least $\geq 5$ knots per hour were included. We made observations during the entire period of sunlight (24 running hours) from the ship's bridge ( $15 \mathrm{~m}$ above sea level) and from the external ailerons using the 10 minutes bird counting method (Tasker et al. 1984). All birds flying or resting on ice observed within a $180^{\circ}$ visual field from the ship's sides and bow at a far $\sim 500 \mathrm{~m}$ were recorded. Follower birds were recorded at the beginning of each count. Sampling efforts were restricted to times when sea conditions ranged from zero to seven on the Beaufort scale. The species were observed with naked eyes and then identified at the lowest possible taxonomic level using Nikon Aculon $16 \times 50$ binoculars. If identification at the species level was not possible, they were recorded as "unidentified species". Photographs were taken with a digital camera Sony DSC-HX300 equipped with a $60 \times$ zoom lens to assist in the identification of species through comparisons with catalogues (Shirihai 2009, Orgeira 2014) and personal photograph files.

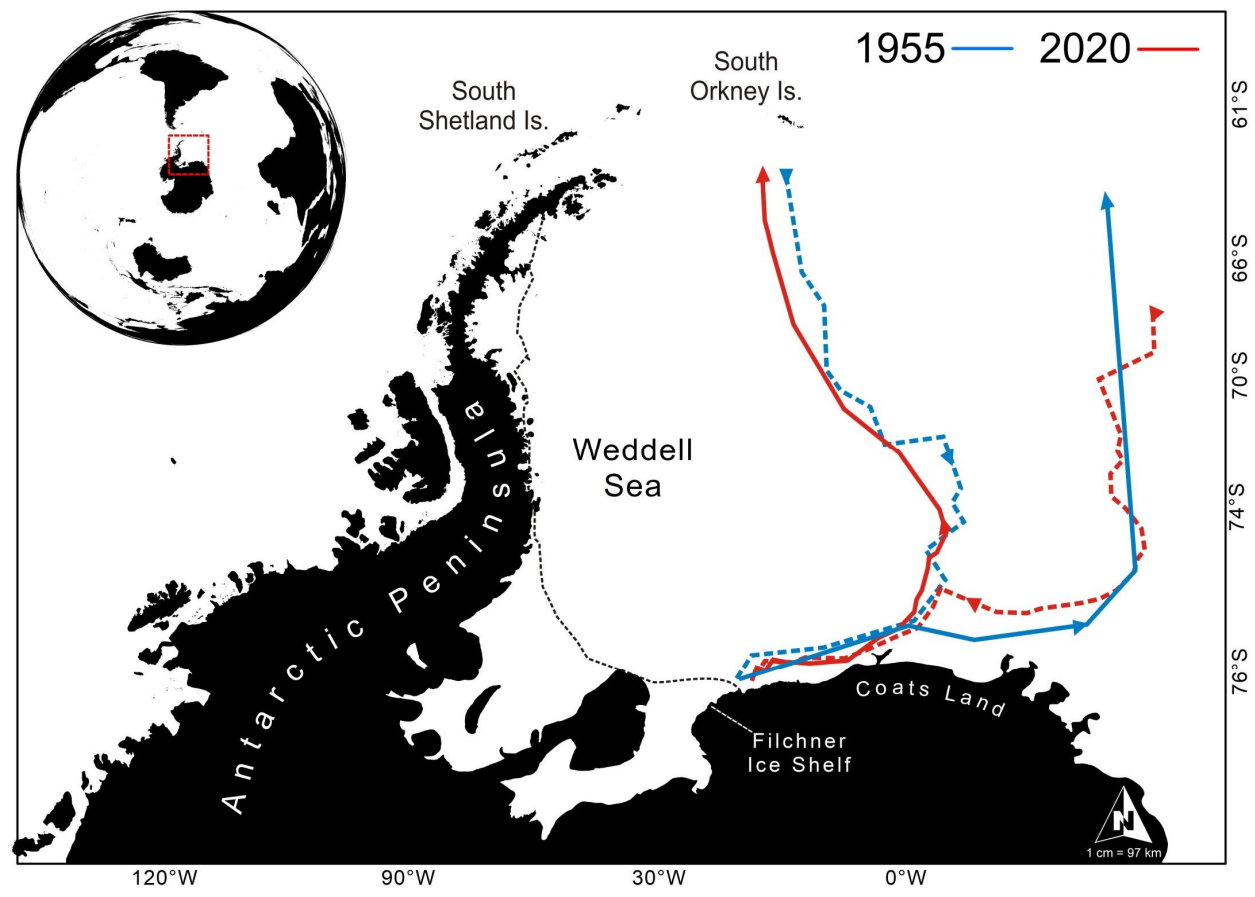

Fig. 1. Study site. Lines represent the ship cruises. Dotted lines are N-S transects; solid lines are S-N transects.

\section{Ice cover estimation}

The ice cover, expressed as a percentage of area, was calculated in situ by observers' visual estimation and supple- mented with satellite images analysis. The observers' estimation was obtained in each 10 minutes count by calculating the per- 
centage of ice present within the $180^{\circ}$ visual field and was validated with the information from the satellite images.

The remote sensing estimation was carried out throughout the ship's track using 13 free access satellite images, with a time difference less than 36 hours after the ship's route. Seven of the images correspond to the MODIS sensor provided by Global Imagery Browse Services ([1]). The visible spectral region was used with spatial resolution of $250 \times 500 \mathrm{~m}$. Due to the cloud cover along the ship's course, the other six images used in the estimation of ice area were from the Synthetic Aperture Radar ([1]) Sentinel-1, C-band radar operating in the spectral region of microwave

\section{Data analysis}

According to the abundances and frequencies of occurrence, the bird species were grouped into primary species and secondary species (Cline et al. 1969). Primary species included numerically dominant species, more frequently sighted and associated with high ice cover. Secondary species were less numerous, less frequently sighted and associated with variable percentages of ice cover. To evaluate the relationships between species we applied a non-metric multidimensional scaling (NMDS) analysis (Delaney et al. 2000), ordering the data based on the abundance values. From the R software ([3] - R Core Team 2019) and following the script by Borcard et al. (2018), we made a logarithmic transformation of the data using the 'decostand' function and applied the 'metaMDS' function with altGower distance to give greater weight to the abundance values.

Our observations were compared with Novatti's cruise (1962) who conducted the first cruise devoted to the study of the avifauna in the Weddell Sea to the (central frequency $5.405 \mathrm{GHz}$ ) with $50 \mathrm{~m}$ resolution, downloaded from Copernicus Open Access Hub. The Region of Interest (ROI) for the calculation of the ice cover was an area of $100 \mathrm{~km}^{2}$ located every $10 \mathrm{~km}$ along the ship's course, resulting in a total of 280 samples. For the digitization and recognition of sea ice, an unsupervised classification was carried out with the k-means method, using the semiautomatic classification plugin (Congedo 2020) in the QGIS software ([2] - QGIS Development Team, 2020). The ice cover was determined from the number of pixels of sea ice and icebergs in relation to the rest of the classes in each ROI.

Filchner Ice Shelf, from December 1955 to January 1956. Novatti (1962) carried out his observations from the bridge (10 masl) and crow's nest ( $\sim 13$ masl) onboard San Martín icebreaker (Argentine Navy), totalling 24 counts. In his study, he did not mention the observation periods of each counting. In those countings, species composition, richness and species abundances were recorded "during daylight mostly and sometimes during the night". Large aggregations of individuals or hot spots were not estimated numerically but reported as "several hundreds individuals". Data such as percentages of ice cover were omitted, so it is not possible to statistically test all of the data between both cruises. Despite methodological omissions, Novatti's (1962) records were detailed enough to allow comparisons of richness, species composition and, where possible, abundances. All transects (1955/56 and 2020) started and ended at $64^{\circ} \mathrm{S}$ except for our N-S transect (23 - 26 January, 2020), which started at $68^{\circ} \mathrm{S}$ due to bad weather conditions. 


\section{Results}

During the 2020 cruises, a total of 1891 birds belonging to 15 species were recorded along approximately $1843 \mathrm{~km}, 373$ tenminute counts and 125 hours of observation were done (Table 1, Fig. 1). Four of the 15 registered species accumulated more than $85 \%$ of the total abundance: Antarctic petrel Thalassoica antarctica $(43.9 \%)$, snow petrel Pagodroma nivea (16.3\%), Arctic tern Sterna paradisaea (15.2\%) and emperor penguin Aptenodytes forsteri (10.1\%, Fig. 2). The highest abundances of all these primary species occurred south of $72^{\circ} \mathrm{S}$, coinciding with the highest percentages of ice cover $\left(r^{2}=0.01, p\right.$-value $<0.05$, Fig. 3). Regarding the secondary species, some were recorded south of their habitually reported distributions, such as lightmantled sooty albatross Phoebetria palpebrata, two flocks with a total of 26 individuals sighted at $69^{\circ} 30^{\prime} \mathrm{S}, 21^{\circ} 53^{\prime} \mathrm{W}$ (NS transect, Fig. 4), white-chinned petrel Procellaria aequinoctialis, three individuals at $66^{\circ} 32^{\prime} \mathrm{S}, 37^{\circ} 44^{\prime} \mathrm{W}$ and blue petrel Halobaena caerulea, two individuals at $68^{\circ} 93^{\prime} \mathrm{S}, 20^{\circ} 32^{\prime} \mathrm{W}$. In addition, 26 Southern giant petrels (Macronectes giganteus) were recorded south of $75^{\circ} \mathrm{S}, \sim 20$ nautical miles from the Filchner Ice Shelf. The two dimensions of the NMDS represented the variation in the data (Stress $=0.190$ ), showing seven species associated with low latitudes (secondary species) and four associated with high latitudes (primary species, Fig. 5). Regarding the ice coverage, its estimation by remote sensors showed a precision with the k-means method of 0.93 in the N-S transect and 0.86 in the $\mathrm{S}-\mathrm{N}$ transect. In his cruise from $64^{\circ} \mathrm{S}$ to the Filchner Ice Shelf, Novatti (1962) described a community of 13 species, 11 of which were also present in our study. Four of these 11 species (Antarctic petrel, emperor penguin, snow petrel and Pygoscelis adeliae) were primary species since they represented more than $90 \%$ of the total abundance. The most numerous species was Antarctic petrel, with at least $50 \%$ of the total.

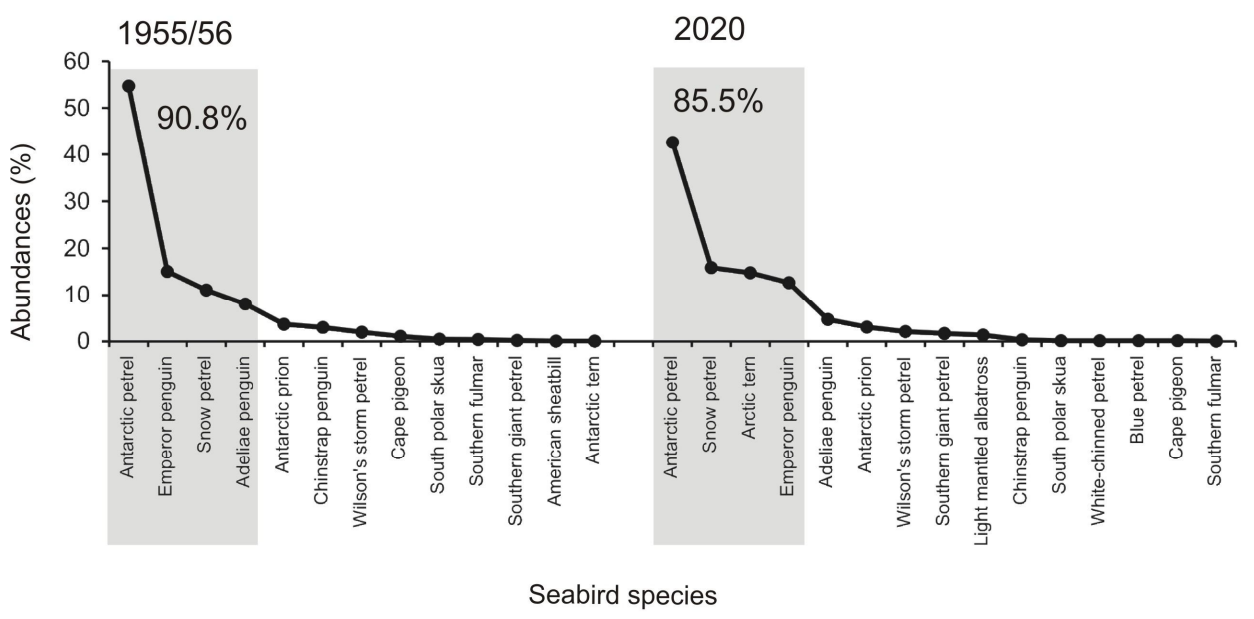

Fig. 2. Comparison between the relative abundances of all the species recorded in $1955 / 56$ by Novatti (1962) and our study (2020). The values of emperor penguin, Antarctic petrel and Antarctic tern for 1955/56 are higher than those expressed (see Table 1). The grey boxes indicate the primary species' cumulative abundance percentages. 


\begin{tabular}{|c|c|c|c|c|}
\hline & $\begin{array}{l}\text { Transect N-S } \\
\text { (23 to } 26 \text { Jan. } \\
2020 \text { ) }\end{array}$ & $\begin{array}{l}\text { Transect S-N } \\
\text { (29 Jan. to } \\
2 \text { Feb. } 2020)\end{array}$ & $\begin{array}{l}\text { Transect N-S } \\
\text { (22 Dec. 1955 } \\
\text { to } 4 \text { Jan. 1956; } \\
\text { Novatti 1962) }\end{array}$ & $\begin{array}{c}\text { Transect S-N } \\
\text { (7 to } 13 \\
\text { Jan. 1956; } \\
\text { Novatti } 1962)\end{array}$ \\
\hline Number of counts & 171 & 202 & - & - \\
\hline Richness & 11 & 12 & 9 & 10 \\
\hline Abundance & 1161 & 730 & $\sim 856$ & $\sim 114$ \\
\hline Surveyed distance & 845 & 998 & - & - \\
\hline $\begin{array}{l}\text { Ice cover (in situ } \\
\text { estimated, \%) }\end{array}$ & 24.4 & 17.4 & - & - \\
\hline $\begin{array}{l}\text { Ice cover (satellite } \\
\text { estimated, } \% \text { ) }\end{array}$ & 23 & 15.5 & - & - \\
\hline Air temperature $\left({ }^{\circ} \mathrm{C}\right)$ & -0.66 & -0 & - & - \\
\hline Primary species: & & & & \\
\hline $\begin{array}{l}\text { Antarctic petrel } \\
\text { Thalassoica antarctica }\end{array}$ & $525(0.5)$ & $281(0.35)$ & $428(\mathrm{~m})$ & 57 \\
\hline $\begin{array}{l}\text { Arctic tern } \\
\text { Sterna paradisaea }\end{array}$ & $231(0.19)$ & $51(0.04)$ & 0 & 0 \\
\hline $\begin{array}{l}\text { Emperor penguin } \\
\text { Aptenodytes forsteri }\end{array}$ & $165(0.25)$ & $75(0.11)$ & 163 & $9(\mathrm{~m})$ \\
\hline $\begin{array}{l}\text { Snow petrel Pagodroma } \\
\text { nivea }\end{array}$ & $110(0.33)$ & $190(0.25)$ & 107 & 11 \\
\hline Secondary species: & & & & \\
\hline $\begin{array}{l}\text { Adeliae penguin } \\
\text { Pygoscelis adeliae }\end{array}$ & $41(0.1)$ & $48(0.08)$ & 76 & 18 \\
\hline $\begin{array}{l}\text { Wilson's storm petrel } \\
\text { Oceanites oceanicus }\end{array}$ & $27(0.11)$ & $13(0.04)$ & 7 & 1 \\
\hline $\begin{array}{l}\text { Light-mantled albatross } \\
\text { Phoebetria palpebrata }\end{array}$ & $26(0.01)$ & 0 & 0 & 0 \\
\hline $\begin{array}{l}\text { Southern giant petrel } \\
\text { Macronectes giganteus }\end{array}$ & $26(0.08)$ & $7(0.02)$ & 0 & 2 \\
\hline $\begin{array}{l}\text { Chinstrap penguin } \\
\text { Pygoscelis antarctica }\end{array}$ & $6(0.02)$ & 0 & 31 & 0 \\
\hline $\begin{array}{l}\text { South polar skua } \\
\text { Stercorarius maccormicki }\end{array}$ & $3(0.01)$ & 0 & 0 & 3 \\
\hline $\begin{array}{l}\text { Blue petrel } \\
\text { Halobaena caerulea }\end{array}$ & $1(0.005)$ & $1(0.004)$ & 0 & 0 \\
\hline $\begin{array}{l}\text { Cape pigeon } \\
\text { Daption capense }\end{array}$ & 0 & $2(0.009)$ & 10 & 0 \\
\hline $\begin{array}{l}\text { Southern fulmar } \\
\text { Fulmarus glacialoides }\end{array}$ & 0 & $1(0.004)$ & 4 & 0 \\
\hline $\begin{array}{l}\text { White chinned petrel } \\
\text { Procellaria aequinoctialis }\end{array}$ & 0 & $3(0.01)$ & 0 & 0 \\
\hline $\begin{array}{l}\text { Antarctic prion } \\
\text { Pachyptila desolata }\end{array}$ & 0 & $58(0.06)$ & 30 & 12 \\
\hline $\begin{array}{l}\text { Antarctic tern } \\
\text { Sterna vittata }\end{array}$ & 0 & 0 & 0 & $\mathrm{~m}$ \\
\hline $\begin{array}{l}\text { American sheathbill } \\
\text { Chionis alba }\end{array}$ & 0 & 0 & 0 & 1 \\
\hline
\end{tabular}

Table 1. Species recorded in this study and by Novatti (1962), in order of abundance. The values in parentheses are frequency of occurrence. According to Novatti's records, the " $\mathrm{m}$ " indicates that, in addition to these values, other "hundreds" of individuals were sighted. Therefore, the value shown for these species and in total abundance is lower than the real value. 

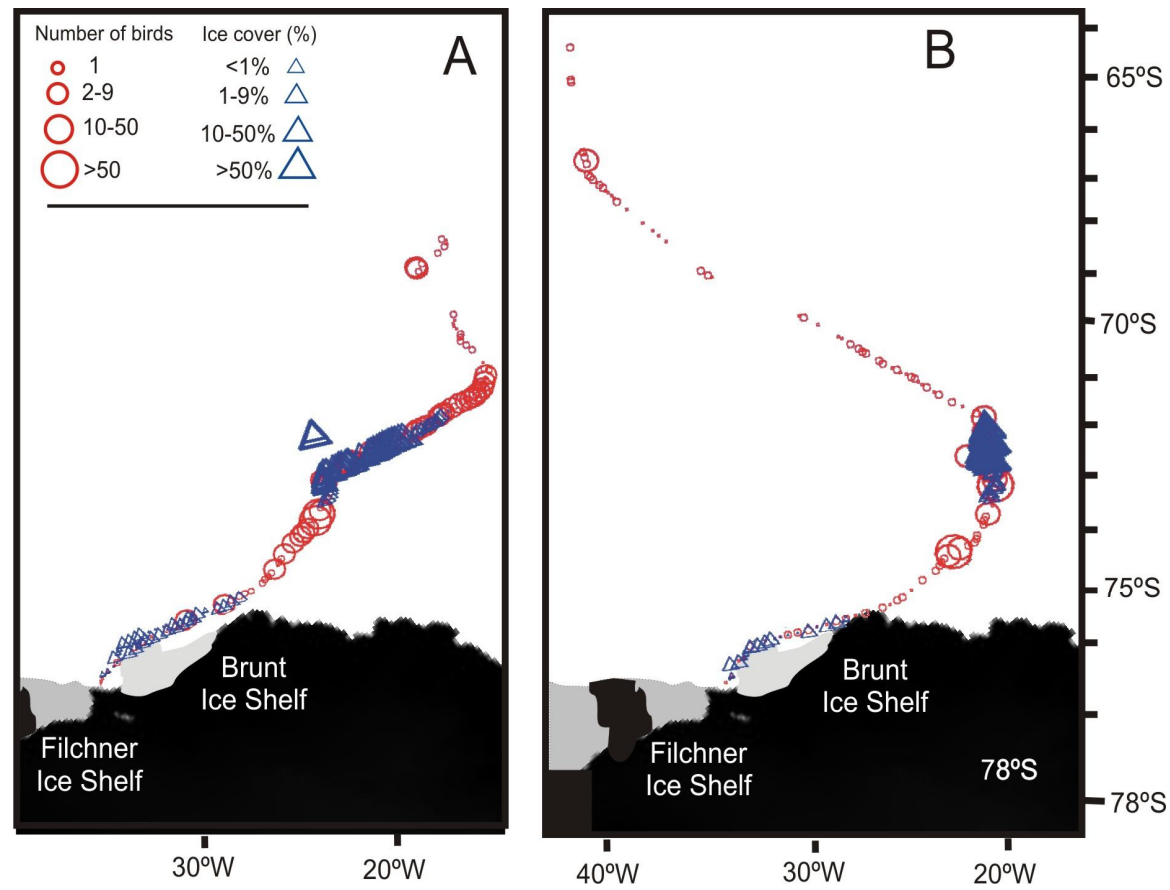

Fig. 3. Bird abundances and ice cover recorded. A: N-S transect (23 to 26 January, 2020), B: S-N transect (29 January to 2 February, 2020). The greatest ice coverage (marine and icebergs, $>50 \%$ ) occurred in the S-N transect.

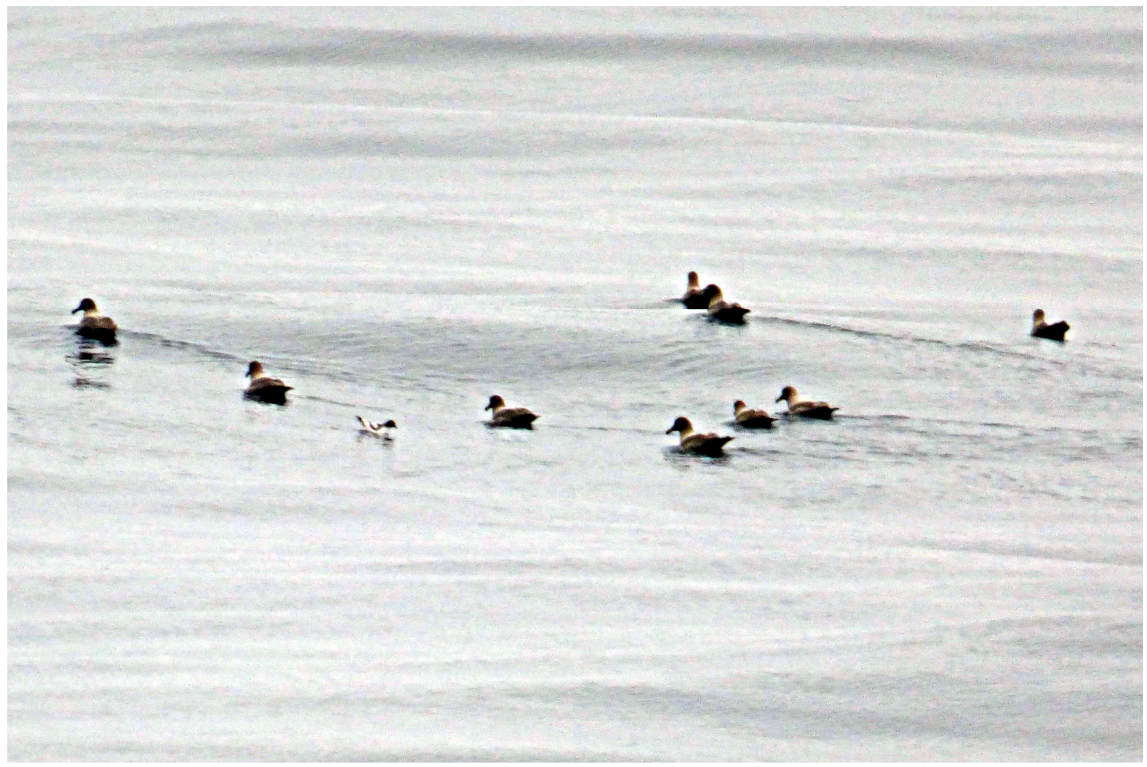

Fig. 4. One of the flocks of Light-mantled albatross, next to Antarctic petrel, recorded in ice-free waters south of $69^{\circ} \mathrm{S}$. Photograph by Y. G. Jiménez. 


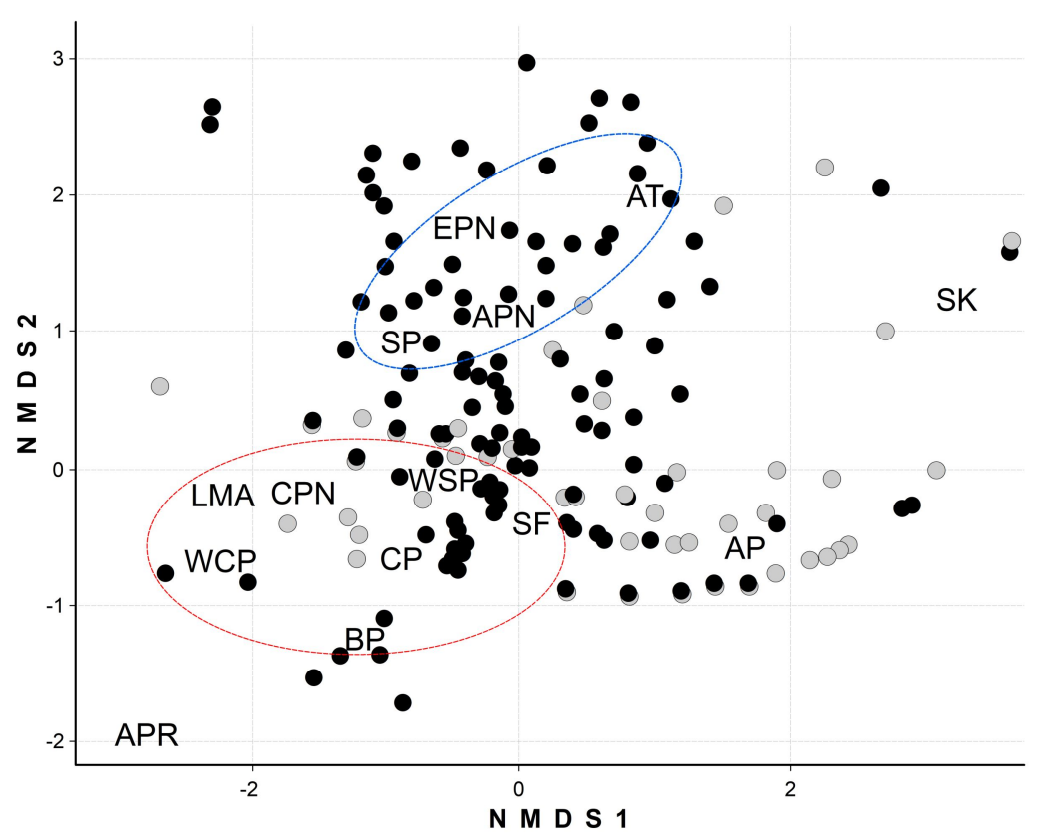

Fig. 5. Ranking scores derived from non-metric multidimensional scale (NMDS) analysis of the species composition matrix recorded in January / February 2020. EPN - emperor penguin, AT - Arctic tern, APN - Adeliae penguin, SP - snow petrel, SK - South polar skua, WSP Wilson's storm petrel, CPN - chinstrap penguin, LMA - light mantled albatross, SF - Southern fulmar, AP - Antarctic petrel, CP - cape pigeon, WCP - white-chinned petrel, BP - blue petrel, APR - Antarctic prion.

\section{Discussion}

Comparisons between the 1955/56 2020 cruises revealed some persistence in terms of richness, species composition and even abundances, since in both studies the same species could be categorized as primary species and secondary species. Two factors might be favouring such persistence: (1) the presence of reproductive colonies of primary species within the study site, and (2) the ice cover. Regarding the reproductive colonies, it's known that seven species (four primary species and three secondary species) are residents, nesting in continental or insular areas bordering the Weddell Sea: Antarctic petrel and Snow petrel nesting in the Theron Mountains (Brook and Beck 1972), about $100 \mathrm{~km}$ south of the Filchner Ice Shelf. In addition, there are other colonies of Antarctic Petrel in Dronning Maud Land and Coats Land (van Franeker 1996). Adeliae penguin has numerous breeding colonies on the continental margin (Shirihai 2009, Pehlke et al. 2019) and Emperor penguin breed on the pack-ice in adjacent seas and on Snow Hill Island, which is still the northernmost known colony for this species (Coria and Montalti 2000). Antarctic petrel was the only numerically dominant species in both cruises, exceeding $40 \%$ of the total in the two cases. Species close to or greater than $50 \%$ of the total abundance were called hyper-dominant species (ter Steege et al. 2017). The concept of hyper-dominant species was used in high biodiversity environments (Amazon biome), and it is also 
applicable to our study due to the parallelism of the concept and the importance that these species represented within their ecosystem as numerically dominant species. As a hyperdominant species, the Antarctic petrel has a wide pelagic distribution within the study site, while other species were restricted to the north or south. It represents half (or more) of the entire Weddell Sea bird community and all of its known colonies are found on the Antarctic continent. Because its main forage areas are in ice-covered waters, Antarctic petrel can be highly vulnerable to changes caused by thermal increases. Recent studies suggest that, in the austral summer, a significant part of the Antarctic petrel population forage in the Lazarev Sea, off the Fimbul ice shelf (Descamps et al. 2016, Pehlke et al. 2019), while west of the Antarctic peninsula the largest aggregations of this species occur in ice fields (Joiris et al. 2013).

As for the secondary species, Wilson's storm petrel Oceanites oceanicus nests in Bertrab Nunatak, Filchner Ice Shelf (Orgeira and Recabarren 1993, Orgeira 1994, 2000; Vélez 1995). South polar skua Catharacta maccormicki and probably Southern giant petrel Macronectes giganteus nest in the Theron Mountains (Brook and Beck 1972) about $100 \mathrm{~km}$ south of the Filchner Ice Shelf. Two other species, Cape pigeon Daption capense and Southern fulmar Fulmarus glacialoides, nest on the Antarctic continent east of the study site (Watson 1975, Shirihai 2009). All these species had been also recorded by Novatti (1962) with details of their abundances, which allowed them to be categorized as secondary species. Sightings of the Southern giant petrel in our study were relevant since solitary specimens have been reported recurrently in the central and southern Weddell Sea since 1955 (Novatti 1962), even flying over the Nunatak Bertrab and the Filchner Ice Shelf (O. Fogliatto, pers. com.). Recurring sightings of this species suggest that it could be nesting nearby or more likely in the Theron Mountains, alongside the colonies of Antarctic petrel, snow petrel, and South polar skuas. NMDS analysis confirmed the separation of the Weddell Sea bird community into two groups (primary species and secondary species) with three isolated species, Antarctic petrel, Antarctic prion and South polar skua (Fig. 5). The separation of Antarctic petrel from the primary species group is due to the fact that it is the only one of all the 15 species recorded with a continuous presence along the N-S and S-N transects. On the contrary, pairs or small flocks of Antarctic prion were recorded north of the study site and isolated specimens of South polar skua were sighted south of the Weddell Sea, in the vicinity of the ice shelves.

Regarding ice coverage, the free-drifting icebergs in the Weddell Sea were considered as hot spots of continual micronutrient release that sustain the accompanying epibiotic and pelagic communities (Olivier et al. 2005, Smith et al. 2007). Thus, the seabird abundances is 2 to 6 times greater within about $0.5 \mathrm{~km}$ of free drifting icebergs than the area between about 0.5 and $1 \mathrm{~km}$ from the iceberg edge (Ruhl et al. 2011). In addition, the surfaces of the large tabular icebergs are often used as resting areas by species such as Antarctic petrel, snow petrel or Arctic tern in large numbers (Orgeira 1998, Olivier et al. 2005, Joiris 2017). These bird-drift ice relationships contribute to explain the abundance patterns obtained in this study since the largest bird aggregations occurred south of $72^{\circ} \mathrm{S}$ in the presence of the highest ice concentrations (Figs. 3 and 6) while the lowest bird abundances occurred north of $72^{\circ} \mathrm{S}$, in ice-free waters. On the other hand, it has been proposed for decades that some species are favored by the presence of sea ice and icebergs (Antarctic and snow petrel; Olivier et al. 2005), while others are excluded (albatrosses, large procellariiforms; Griffiths 1983). 

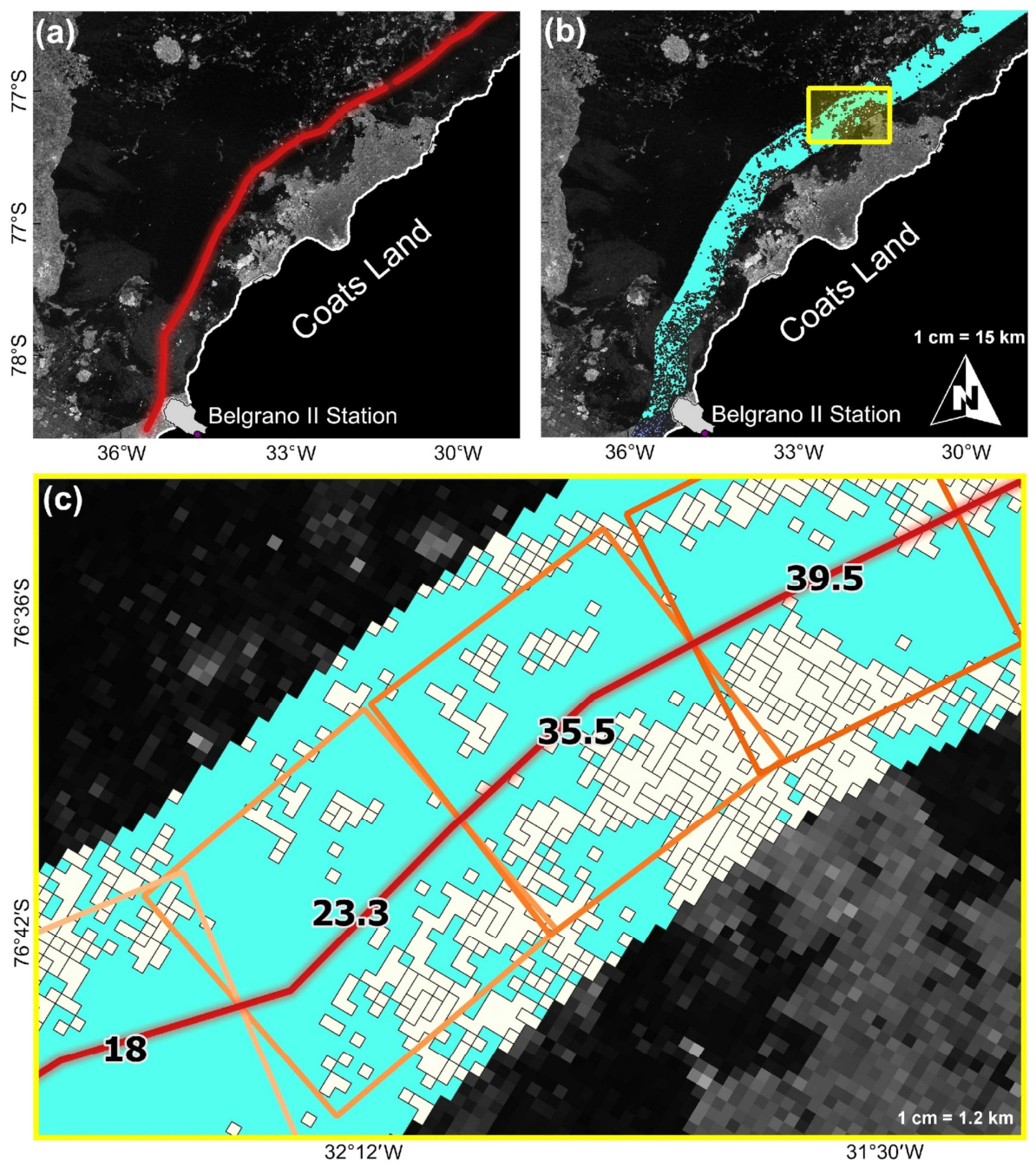

Fig. 6. a) Almirante Irizar icebreaker track (red line) towards Belgrano II Station; b) classification of the ice cover generated throughout the ship's track in Sentinel-1 image; c) Detail of the classification showing the ROI (regions of interest) and the ice cover (percentages) calculated for each unit.

In our study, the presence of species such as light-mantled albatross, whitechinned petrel and blue petrel, in the central and southern Weddell Sea, may be favoured by the absence of ice but restricting the distributions of other ice dependent species. Since Novatti (1962) did not use any method to quantify the amount of ice, it is not possible to compare the two cruises in terms of this environmental variable. However, he described "severe ice conditions", registering the highest bird abundances south of $69^{\circ} \mathrm{S}$. The absence of Arctic tern in the summer season 1955/56 was notable since it is a migratory species from the Northern Hemisphere that visits 
Antarctica in the southern summer (Watson 1975, Shirihai 2009, Orgeira 2014). Arctic terns spend the period of from November to March in the Antarctic ice zone exploiting the rich supply of krill in the upwelling waters and while molting their feathers (about 60 days), they are hampered in their flight and spend a lot of time resting in the ice (Alerstam et al. 2019). Due to its abundance and sightings frequency in the Weddell Sea, it is a primary species. However, the only terns recorded in the 1955 cruise were "hundreds" of Antarctic terns Sterna vittata on the Larsen Ice Shelf, off Robertson Island, south of $65^{\circ} \mathrm{S}$. Therefore, due to the above facts (missing quantitative data from 1995), the comparison of terns is not possible.

In the last 61 years, disintegration of glaciers has been recorded on the East and West of the Antarctic Peninsula due to global atmospheric warming (Cook et al. 2005, Rogers et al. 2020, Turner et al. 2020) and scientists understood that climatically-driven variations in iceberg abundance would influence local seabird distributions with unknown impacts on regional abundances and species composition (Ruhl et al. 2011). It is well established that significant changes in ecosystem structure are generated from changes in primary producers and consumer populations that are propagating through the food chain (Rogers et al. 2020). This is particularly alarming in the central and the southern Weddell Sea bird community where more than $85 \%$ of its abundance is represented by only four hyper-dominant species which, in addition, are dependent on ice cover. It has also been shown that breeding performance variability is partly controlled by environmental factors such as sea ice extent variations in species such as the snow petrel (Olivier et al. 2005).

Since the 1950 s, successive increases in air temperature in the Antarctic Peninsula, the North Weddell Sea and the South Orkney Islands have been documented
(Zazulie et al. 2010, Rogers et al. 2020, Turner et al. 2020) and warnings have already been made about the risk of further ice shelf thinning and the potential for a dramatic rise of the sea level (Daae et al. 2020). To prove this, there have been nine major calving events in the ice shelves around the Weddell Sea since 2017, from the origin of the A68 iceberg (July 12, 2017 in the Larsen C Ice Shelf) to A76 (13 of May 2021 in Ronne Ice Shelf). One year after our cruise, another large iceberg broke off the Brunt Ice Shelf (A-74, February 27,2021$)$. The sea ice concentration also suffered a marked decrease in the study site over summer 2013/2015 2016/2017 (Turner et al. 2020). In the study site, the sea ice extent showed negative trends in the last decade (Turner et al. 2017, Parkinson et al. 2019) and suffered a marked decrease over summer 2013/20152016/2017 (Turner et al. 2020).

Other studies indicate that meltdowns of ice shelves and glaciers south of the Weddel Sea were recorded less frequently than in the rest of Antarctica and the annual average calving mass was negligible in the study site for 2005 to 2019 as Ronne-Filchner ice shelf (Qi et al. 2021). Some authors suggest that due to ice cover and ocean currents, the Weddell Sea is expected to be one of the last regions of the Southern Ocean where the consequences of climate change will manifest, serving as refuge for species dependent on sea ice (Olivier et al. 2005, Teschke et al. 2021). For this reason, the seabird community could present a delay in manifesting an impact, without showing the direct relationships that we expected to find when comparing two studies spaced by 65 years. We believe that such climatic changes will be inevitable in the Weddell Sea. Until these changes happen, the Weddell Sea bird community is likely to remain relatively stable in richness, species composition, and abundances. 


\section{Conclusions}

This study compares two cruises spaced 65 years apart in a highly dynamic and variable area in terms of thermal records, quantity, type and ice distribution. Despite these variabilities, we find similarities in the species composition, richness and abundances. These results suggest that the central and southern Weddell Sea avifauna has a persistence that might depend on the population status of the nesting species in the site (mainly Nunatak Bertrab and the Theron Mountains, which is unknown) and the quantity, dynamics and distribution of the ice cover. Statistically significant warming was evident in Antarctica since 1950 , so the $1955 / 56$ cruise was carried out at the beginning of a process of climate change intensification that is still ongoing. Therefore, these studies constitute a valuable historical background that we must take into account to understand possible changes in birdlife and its environment.

\section{References}

Ainley, D., Tynan, C. and Stirling, I. (2003): Sea ice: a critical habitat for polar marine mammals and birds. In: D. N. Thomas, G. S. Dieckmann (eds.): Sea ice: An introduction to its physics, chemistry, biology and geology. Blackwell Publishing, Oxford, pp. 240-266.

Alerstam, T., BÄCKMAn, J., GrÖNROOS, J., Olofsson, P. and StRANDBERG, R. (2019): Hypotheses and tracking results about the longest migration: The case of the arctic tern. Ecology and Evolution, 9 (17): 9511-9531.

Borcard, D., Gillet, F. and Legendre, P. (2018): Canonical Ordination. In: Numerical ecology with R. Use R!. Springer, Cham. https://doi.org/10.1007/978-3-319-71404-2_6

BROOK, D., BECK, J.R. (1972): Antarctic petrels, snow petrels and south polar skuas breeding in the Theron Mountains. British Antarctic Survey Bulletin, 27: 131-137.

Cline, D. R., Siniff, D. B. and ERickson, A.W. (1969): Summer birds of the pack ice in the Weddell Sea, Antarctica. The Auk, 86: 701-716.

Congedo, L. (2020): Semi-automatic classification plugin documentation. doi: 10.13140/RG.2.2. $25480.65286 / 1$

Cook, A. J., Fox, A. J., Vaughan, D. G. and Ferrigno, J. G. (2005): Retreating glacier fronts on the Antarctic peninsula over the past half-century. Science, 308: 541. doi: $10.1126 /$ science. 1104235

Coria, N. R., Montalti, D. (2000): A newly discovered breeding colony of emperor penguins Aptenodytes forsteri. Marine Ornithology, 28: 119-120.

Daae, K., Hattermann, T., Darelius, E., Mueller, R. D., Naughten, K. A., Timmermann, R. and Hellmer, H. H. (2020): Necessary conditions for warm inflow toward the Filchner Ice Shelf, Weddell Sea. Geophysical Research Letters, 47: e2020GL089237. doi: 10.1029/ 2020GL089237

Delaney, C. W., Ruiz, M., Clarke, M. and Srinivasan, P. (2000): Knowledge discovery in databases: Data mining the NMDS. In: Proceedings of the $7^{\text {th }}$ International Congress on Nursing Informatics: One Step Beyond: The Evolution of Technology \& Nursing, pp. 61-65.

Descamps, S., Tarroux, A., Cherel, Y., Delord, K., Godø, O. R., Kato, A., Krafft, B. A., Lorentsen, S.-H., Ropert-Coudert, Y., Skaret, G. and Varpe, Ø. (2016): At-Sea distribution and prey selection of Antarctic petrels and commercial Krill Fisheries. PLoS ONE, 11(8): e0156968. doi: 10.1371/journal.pone. 0156968

Ferreyra, G. A., Schloss, I. R. (1993): Campaña Irizar 1988/89 - datos preliminares proyectos frentes oceánicos antárticos (FOCA). Cont. Inst. Ant. Arg. N $\mathrm{N}^{\circ} 413$.

GRIFFITHS, A. M. (1983): Factors affecting the distribution of the snow petrel (Pagadroma nivea) and the Antarctic petrel (Thalassoica antarctica). Ardea, 71: 145-150. 
JOIRIS, C. R. (1991): Spring distribution and ecological role of seabirds and marine mammals in the Weddel Sea, Antarctica. Polar Biology, 11: 415-424.

JoIRIS, C. R. (2017): Seabird hotspots on icebergs in the Amundsen Sea, Antarctica. Polar Biology, 41: 111-114 (2018). doi: 10.1007/s00300-017-2174-4

Joiris, C. R., Humphries, G. R. W. and De Broyer, A. (2013): Seabirds encountered along return transects between South Africa and Antarctica in summer in relation to hydrological features (2013). Polar Biology, 36: 1633-1647. doi: 10.1007/s00300-013-1382-9

Kahru, M., Mitchell, B. G., Gille, S. T., Hewes, C. D. and Holm-Hansen, O. (2007): Eddies enhance biological production in the Weddell-Scotia Confluence of the Southern Ocean. Geophysical Research Letters, 34: L14603. doi: 10.1029/2007GL030430

Moore, K. J., Aввотt, M. R. (2002): Surface chlorophyll concentrations in relation to the Antarctic Polar Front: seasonal and spatial patterns from satellite observations. Journal of Marine Systems, 37: 69-86.

NovatTi, R. (1960): Observaciones sobre aves oceánicas en el Mar de Weddell durante el verano 1959-60. Contribución del Instituto Antártico Argentino, 53: 1-19.

NovatTi, R. (1962): Distribución pelágica de aves en el Mar de Weddell. Contribución del Instituto Antártico Argentino, 67: 1-22.

Olivier, F., van Franeker, J. A., Creuwels, J. C. S. and Woehler, E. J. (2005): Variations of snow petrel breeding success in relation to sea-ice extent: detecting local response to largescale processes? Polar Biology, 28: 687-699. doi: 10.1007/s00300-005-0734-5

Orgeira, J. L. (1994): Registros del Petrel de Wilson (Oceanites oceanicus) en el Mar de Weddell, Antártida. Contribución del Instituto Antártico Argentino, 436: 1-5.

OrgeirA, J.L. (1998): Distribución de aves en el Mar de Weddell, Antártida, verano de 1990. Contribución del Instituto Antártico Argentino, 438: 1-16.

OrgeirA, J. L. (2000): Avifauna del Nunatak Bertrab, barrera de hielos Filchner, Antártida, periodo 1995 -1996. Ornitología Neotropical, 11: 177-182.

Orgeira J. L. (2014): Guía de Campo para la identificación de Aves Antárticas. Dirección Nacional del Antártico - Instituto Antártico Argentino. Ciudad Autónoma de Buenos Aires, pp. $1-102$.

Orgeira, J. L., Recabarren, P. (1993): Ornithological observations at Belgrano II Station, Filchner Iceshelf, Antarctica. Marine Ornithology, 21: 74-77.

PARKINSON, C. L. (2019): A 40-y record reveals gradual Antarctic Sea ice increases followed by decreases at rates far exceediered a marked decrease over summer 2013/2015-2016/2017. 116(29): 14414-14423.

Plotz, J., Weidel, H. and Bersch, M. (1991): Winter aggregations of marine mammals and birds in the north-eastern Weddell Sea pack ice. Polar Biology, 11: 305-309.

Pehlke, H., Brey, T. and Teschke, K. (2019): Spatial distribution of a flying seabird (Antarctic petrel) and penguins (Adelie penguin, Emperor penguin) in the wider Weddell Sea (Antarctica) with links to ArcGIS map packages, PANGAEA. doi: 10.1594/PANGAEA.899520

Qi, M., Liu, Y., Liu, J., Cheng, X., Feng, Q., Shen, Q. and Yu, Z. (2021): A 14-yr CircumAntarctic Iceberg calving dataset derived from continuous satellite observations. Earth System Science Data Discussions [preprint], in review. doi: 10.5194/essd-2020-340

Rogers, A. D., Frinault, B. A. V., Barnes, D. K. A., Bindoff, N. L., Downie, R., Ducklow, H. W., Friedlaender, A. S., Hart, T., Hill, S. L., Hofmann, E. E., Linse, K., McMahon, C. R., Murphy, E. J., Pakhomov, E. A., Reygondeau, G., Staniland, I. J., Wolf-Gladrow, D. A. and WRIGHT, R. (2020): Antarctic futures: An assessment of climate-driven changes in ecosystem structure, function, and service provisioning in the Southern Ocean. Annual Review of Marine Science, 12: 87-120.

Ruhl, H. A, EllenA, J. A, Wilson, R. C. and Helly, J. J. (2011): Seabird aggregation around freedrifting icebergs in the northwest Weddell Sea and Scotia Seas. Deep-Sea Research II, 58: 1497-1506.

SCHNEPPENHEIM, R. (1981). Results of the biological investigations in the Weddell Sea during a Site Survey 1979/80. Polarforschung, 51(1): 91-99. 
Shirihai, H. (2009): A complete guide to Antarctic wildlife. The birds and marine mammals of the Antarctic continent and the Southern Ocean. $2^{\text {nd }}$ edn. Princeton: Princeton University Press. $544 \mathrm{p}$.

Smith, K. L. JR., Robison, B. H., Helly, J. J., Kaufmann, R. S., Ruhl, H. A., Shaw, T. J., Twining, B. S. and Vernet, M. (2007): Free-drifting icebergs: Hot spots of chemical and biological enrichment in the Weddell Sea. Science, 317: 478-482. doi: 10.1126/science.1142834

TAsker, M. L., Jones, P. H., Dixon, T. and Blake, B. F. (1984): Counting seabirds at sea from ships: a review of methods employed and a suggestion for a standardized approach. Auk, 101: 567-577.

ter Steege, H., Pitman, N. C. A., Sabatier, D., et al. (2017): Hyperdominance in the Amazonian tree flora. Science, 342(6156): 1243092. doi: 10.1126/science.1243092

Teschke, K., Brtnik, P., Hain, S., Herata, H., Liebschner, A., Pehlke, H. and Brey, T. (2021): Planning marine protected areas under the CCAMLR regime - The case of the Weddell Sea (Antarctica). Marine Policy, 124: 104370.

Thurston, M. H. (1982): Ornithological observations in the South Atlantic Ocean and Weddell Sea, 1959-64. British Antarctic Survey Bulletin, 55: 77-103.

Turner, J., Phillips, T., Marshall, G. J., Hosking, J. S., Pope, J. O., Bracegirdle, T. J. and Deb, P. (2017): Unprecedented springtime retreat of Antarctic sea ice in 2016. Geophysical Research Letters, 44: 6868-6875. doi: 10.1002/2017GL073656

Turner, J., Guarino, M. V., Arnatt, J., Jena, B., Marshall, G. J., Phillips, T., Cc, B., Clem, K., Wang, Z., Andersson, T., Murphy, E. and Cavanagh, R. (2020): Recent decrease of summer sea ice in the Weddell Sea, Antarctica. Geophysical Research Letters, 47: e2020GL087127. doi: 10.1029/2020GL087127

VAN FRANEKER, J. A. (1992): Top predators as indicators for ecosystems events in the confluence zone and marginal ice zone of the Weddell and Scotia seas, Antarctica, November 1988 to January 1989 (EPOS Leg 2). Polar Biology, 12: 93-102.

VAN FRANEKER, J. A. (1996): Pelagic distribution and numbers of the Antarctic petrel Thalassoica antarctica in the Weddell Sea during spring. Polar Biology, 16(8): 565-572.

VÉLEZ, L. G. (1995): Wilson's Storm Petrels Oceanites oceanicus breeding at the Bertrab Nunatak, Filchner Iceshelf, Antarctica. Marine Ornithology, 23: 67.

Watson, G. E. (1975): Birds of the Antarctic and Sub-Antarctic. American Geophysical Union, Washington, D.C., $350 \mathrm{p}$.

Zazulie, N., Rusticucci, M. and Solomon, S. (2010): Changes in climate high Southern latitudes: A unique daily record at Orcadas spanning 1903-1908. American Meteorological Society, 23: 189-196.

ZINK, R. M. (1978): Birds of the Weddell Sea. Antarctic Journal of the United States, 13: 142-145.

\section{Web sources / Other sources}

[1] We acknowledge the use of imagery provided by service from NASA's Global Imagery Browse Service (GIBS), part of NASA's Earth Observing System Data and Informatioon System (EOSDIS). https://earthdata.nasa.gov

[2] QGIS Development Team (2020): QGIS Geographic Information System (version 3.10). Open Source Geospatial Foundation Project.http://qgis.osgeo.org

[3] R Core Team (2019): R: A language and environment for statistical computing. R Foundation for Statistical Computing, Vienna, Austria. ISBN 3-900051-07- 0. http://www.R-project.org/

[4] R Development Core Team (2020): R: A language and environment for statistical computing. R Foundation for Statistical Computing, Vienna, Austria. ISBN 3-900051-07-0. http://www. R-project.org/ 